
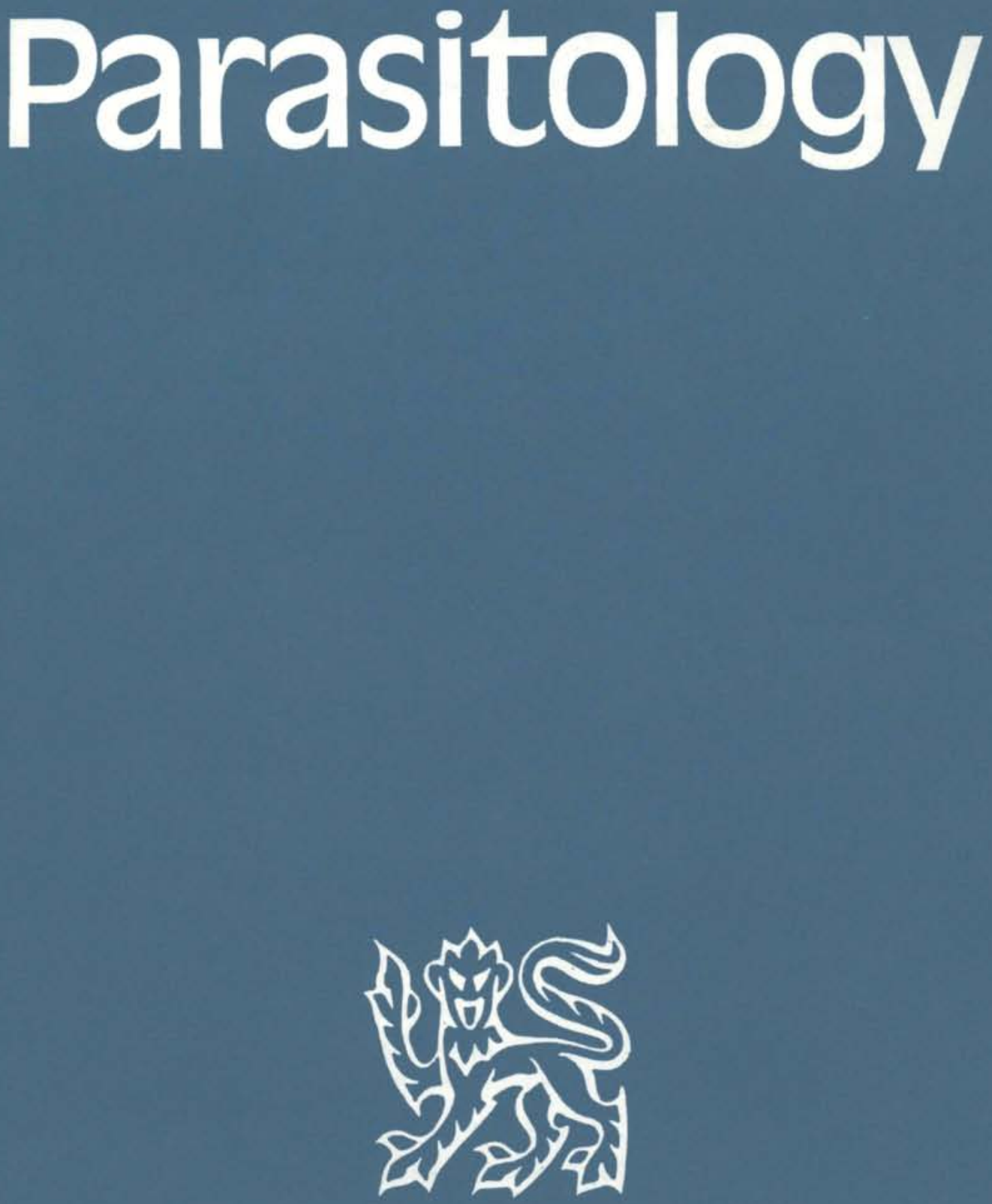


\title{
PARASITOLOGY
}

(FOUNDED BY G. H. F. NUTTALL)

EDITORS

\author{
D. W. T. CROMPTON and B. A. NEWTON \\ The Molteno Institute, Downing Streot, \\ Cambridge, England \\ EDITOKLAL ASSISTANT \\ SA.YDRA K. RAY, M.A. PL.D.
}

EDITORIAL POLICY

Parasitology publishes original results from pure and applied studies of parasites and hostparasite relationships. In adelition to papers describing the taxonomy, life-cycles and ecology of parasites, the editors will bepleased to consider reports of experimental work on biochemical, immunological and physiological aspects of parasitism and the chernotherapy of parasitic diseases. Contributors are strongly advised to prepare their typescripts in the manner set out in the Instructions to Authors included in each part of the journal. The editors ussume that papers submitted to Parasitology are not being consideres for publication in other journals and do not contain material which has alrealy been published.

\section{EDITOBIAL. BOARD}

GWENDOLEN REES, F.R.S. (Chuirman)
D. IR. ARTHUR
D. L. LEE
S. COHEN
J. LLEWELLYN
C. ELLENBY
IV. F, MAI
L. G. GOODWIN
S. R. SWITHERS
C. A. HOPKINS
P. TATE

C. ARME
R. A. AVERY
J. R. BAKER
J. BARRETT
ELIZABETH U. CANNING
THERESA CLAY
R. M. CONAAY
R. R. A. COOMBS, F.R.S.
G.A. M. CROSS

C. ARME

J.R.BAKER

PARASTTOLOGY is published onee every two month. Each volume consists of three parts (published in February, April. June, August, October and December) plus an index.

SECOND OLASS POSTAGE PAID AT NEW YOKK, N.Y.

Information on subscriptions, baok volumes, permissions and advertising is given on the inside back cover.

1974 subseription per volume: $£ 11.00$ net (US $\$ 35.00$ in the U.S.A. and Canada) 3 parts Single parts: $£ 5.00$ net (US $\$ 15.00$ )

C) Cambridge University Press 1974

Bentley House, 200 Euston Road, London XW1 2DB

American Branch: 32 East 57th Street, New York, X.Y. 10022 


\section{PARASITOLOGY}

\section{INSTRUGTIONS TO AUTHORS}

1 Manuscripts, which must be written in English, should be sent to The Editors, Parasitology, The Molteno Institute, Downing Street, Cambridge, CB2 3EE, U.K.

2 Authors should prepare manuscripts for Parasitology in the style of papers published in recent parts of the journal.

3 Manuscripts must be typewritten, in double spacing throughout (including references, tables, legends and keys to the abbreviations used on figures and plates) and sheets should be numbered consecutively. Tables should be typed on separate sheets and should be self-explanatory.

4 A short title of not more than 44 characters, for use as page headings, should be supplied if the title is longer than this.

5 References must be given in alphabetical order of authors' names. The title of the journal should be given in full. The following style should be used:

Eveland, L. K. \& RITCHIE, L. S. (1972). Infectivity of cercariae of Schistosoma mansoni from snails on inadequate diets. Parasitology 64, 441-4.

Rogers, W. P. (1962). The Nature of Parasitism. New York and London: Academic Press.

HoNIaBERG, B. M. (1967). Chemistry of parasitism among some protozoa. In Chemical Zoology, vol. I (ed. M. Florkin, B. T. Scheer and G. W. Kidder), pp. 695-814. New York and London: Academic Press.

Citations in the text should be given in the following form: Brown \& Green $(1960)$ or (Brown \& Green, 1960). Where there are more than two authors the first citation should include all the names, and subsequent citations should be in the form (Brown et al.). Where more than one paper by the same author(s) have been published in the same year they should be cited as Brown (1960a), Brown (1960b), etc.

6 SI units should be used throughout in the preparation of manuscripts.

7 Text figures should be drawn about twice the size of the finished block. The maximum printed size of any drawing or group of drawings is $200 \mathrm{~mm}$ by $125 \mathrm{~mm}$. Explanatory lettering will be inserted by the printers and should be indicated on drawings in faint blue pencil or on a tracing-paper overlay. Scales of magnification should be given alongside the illustrations. Drawings, diagrams and graphs should be referred to in the text as Fig. 1, Fig. 2, etc.

8 Photographs should be the same size as they are to appear in the journal. The maximum area for a plate is $200 \mathrm{~mm}$ by $125 \mathrm{~mm}$. Photographs should be referred to in the text as Pl. 1, Pl. 2, etc. Where several photographs make up a plate they should be accurately mounted on card and referred to in the text as Pl. 1 A, Pl. 1B, etc. Lettering on plates will be inserted 
by the printers and should be indicated on a tracing-paper overlay. Authors may be asked to contribute to the cost of plates in excess of four.

9 Nomenclature of organisms. Authors should follow the International Rules of Nomenclature. When new names are introduced the recommendations of the International Code of Zoological Nomenclature should be followed.

10 Nomenclature of chemicals and enzymes. Chemical nomenclature should be according to the 1972 revision of Policy of the Journal and Instructions to Authors, The Biochemical Society, 7 Warwick Court, London, W.C.1. Enzyme nomenclature should follow the system published in Report on the Commission on Enzymes of the International Union of Biochemistry (Oxford: Pergamon Press).

11 Authors will receive 25 offprints free of charge and may order additional copies when proofs are returned. Authors may be charged for excessive alteration in proof.

D. W. T. CROMPTON AND B. A. NEWTON (EDITORS) 